Prevention of Urinary Tract Infection

\title{
Effect of Aseptic Technique versus Routine Hospital Care on Prevention of Catheter Associated Urinary Tract Infection
}

\author{
Amira Mohamed, Clinical Instructor \\ Medical -Surgical Nursing, Faculty of Nursing, Port Said University \\ Amany Shebl Abed El-Lateef, Assistant Professor \\ Medical -Surgical Nursing, Faculty of Nursing, Mansoura University \\ Amal Bakr Abo Elata, Lecturer \\ Medical -Surgical Nursing, Faculty of Nursing, Port Said University
}

\section{Abstract}

Background: The use of indwelling urinary catheters in hospitalized patients presents an increased risk of the development of complications, including catheterassociated urinary tract infection (CAUTI) which is considered the most common healthcare-associated infection (HAI). Using aseptic technique in the care of urinary catheter helps to minimize the risk of this complication. Objective: The aim of this study was to determine the effect of aseptic technique versus routine hospital care on prevention of catheter associated urinary tract infection. Setting: The study was carried out at the Urology departments of El-Zohor General Hospital, El-Mabra Health Insurance Hospital in Port Said City and urology and Nephrology Center in Mansoura University to test the hypothesis that catheter associated urinary tract infection will register low rate by using aseptic technique than using routine hospital care. Subjects: The study included 60 female adult patients in need for urethral catheterization for more than three days. They were equally divided into a study group for implementation of aseptic technique and a control group received the routine hospital care. Tools: Two tools were used for data collections. Tool one consisted of two parts part one included structured interview Sheet to assess patients' bio-socio demographic characteristics, information regarding catheter and drainage bag, knowledge regarding catheterization part two included observation checklist to assess implementation of aseptic technique during urinary catheter insertion and care. Tool two included urine culture schedule.

Results: The results demonstrated that Positive urine culture was higher in the control group $(50.0 \%)$ compared to $(20.0 \%)$ in the study group $(p=0.015)$. The study concluded 
that the incidence rate of UTI among patients with urinary catheter can be decreased through using of aseptic technique compared to using of routine hospital care.

Recommendations: The study recommended the necessity of using aseptic technique practices for insertion and care of indwelling urinary catheter in the study setting and in other similar settings. Providing nurses with ongoing in-service education and training stressing the practices of aseptic technique and correct urinary catheter care.

Keywords: Urinary Catheter, Aseptic Technique, Urinary Tract Infection

\section{Introduction}

Patients have a right to be protected from infection and healthcare staff has a duty to safeguard the wellbeing of their patients. Poor asepsis can lead to the risk of cross transmission of micro-organisms from the healthcare worker's hands (HCW) and/or the equipment to susceptible patient sites and from the environment which can result in serious life threatening infections ${ }^{(1)}$.

Urinary catheter considered one of the most invasive medical devices used in the acute care setting. It involves introducing hollow tube through urethra and into the bladder. The catheter provides continuous flow of urine in patients unable to control micturition or those with obstruction ${ }^{(2)}$.Urinary catheters are a necessity for a substantial percentage of the population, including hospitalized patients, residents in longterm care institutions, and those with various urological or genitourinary disorders ${ }^{(3)}$.

Urinary tract infection (UTI) is the single most common hospital-acquired infection, and many cases of nosocomial UTI are associated with an indwelling urinary catheter. Nearly $25 \%$ of hospitalized patients are catheterized yearly and 10\% develop ${ }^{(4,5,6)}$. Urinary tract infections account for approximately $40 \%$ of all health care associated infections (HCAIs) annually. Fully $80 \%$ of these hospital-acquired urinary tract infections are attributable to indwelling urethral catheters. Over one million nosocomial UTIs occur per year ${ }^{(7,8,9)}$.

Individuals requiring an indwelling catheter are predisposed to the development of CAUTIdue to the presence of an indwelling catheter device. The introduction of a catheter into the bladder circumvents the body's normal defense mechanisms and enables micro-organisms to track up the external catheter surface into the bladder ${ }^{(10,11)}$. Each day the urinary catheter remains in place the risk of infection associated urinary catheter increases $5 \%$ per day. Consequently, it can be estimated that $100 \%$ of the patients are colonized after 20 days of catheterization ${ }^{(12,13)}$. 
Catheter associated urinary tract infection (CAUTIs) are painful for patients and costly for hospitals due to increased length of stay and use of additional resources. Each hospital-acquired (UTI) results in an increased length of stay of 56 days in hospital and has additional cost implications for treatments so, whenever possible, catheterization should be avoided and when it is deemed necessary it should be performed using careful strict aseptic technique $(14,15,16)$

Centers for Disease Control and Prevention Guidelines (CDC, 2008) reported that not all CAUTIs can be prevented, but it is believed that a large number can be avoided by the proper management of the indwelling urinary catheter by using infection control measures, an estimated $17 \%$ to $69 \%$ of (CAUTI) may be prevented .In places where infection control programs can be implemented reduction of morbidity and mortality had proven. ${ }^{(17)}$.

Aseptic technique represents patients' last line of defense from microorganisms during invasive clinical procedures. In terms of preventable healthcare-associated infections (HCAIs), aseptic technique can be seen as the most common and critical infection prevention practice in healthcare setting ${ }^{(18)}$.Effective aseptic technique is dependent on healthcare organizations taking a systematic approach to asepsis management in general. The effective education and training of healthcare workers is paramount $^{(19)}$.
Nurses have the unique opportunity to directly reduce health care associated infections through recognizing and applying evidence based procedures to prevent HAIs among patients and protecting the health of the staff. Clinical care nurses directly prevent infections by performing, monitoring, and assuring compliance with aseptic work practices; providing knowledgeable collaborative oversight on environmental decontamination to prevent transmission of microorganisms from patient to patient ${ }^{(20) \text {, }}$

Urinary catheterization is usually carried out by nurses, who have a professional responsibility to be aware of the risks of infection related to the procedure. Failure to maintain professional knowledge and competence or failure to identify and minimize risk to patients in relation to aseptic technique could be viewed as a failure to meet the standards set out in Nursing ${ }^{(21,22)}$. So, the main concern of the study was to determine the effect of aseptic technique versus routine hospital care on prevention of catheter associated urinary tract infection

\section{Aim of Study}

The aim of this study was to determine the effect of aseptic technique versus routine hospital care on prevention of catheter associated urinary tract infection. 


\section{Research hypothesis:}

Catheter associated urinary tract infection will register low rate by using aseptic technique than using routine hospital care.

\section{Materials and Method}

\section{Materials}

Design: A quasi-experimental research design was used in this study.

Setting: The study was conducted at the urology departments of El-Zohor General Hospital and El-Mabra Health Insurance Hospital in Port Said City and Urology and Nephrology Center in Mansoura University.

Subjects: The subjects of the study included 60 patients in need of indwelling urinary catheter. Patients were selected according to the following criteria female patients who need urethral catheterization for more than three days, on closed urinary drainage system and free from urinary tract infection as proved by first urine culture test.

The sample size was calculated to estimate prevalence rate of catheter associated urinary tract infection of $1.57 \%{ }^{(23)}$. With $3 \%$ absolute precision and a $95 \%$ level of confidence, using the single proportion equation for dichotomous variables (24). After correction for a dropout rate of about $10 \%$, the required sample size was 30 patients; patients were divided into studied and control group. 30 patients in each group .The total sample size were 60 patients.

Tools: Two tools were used in this study Tool I and II were developed by the researcher based on the Identified standards of care needed for care of patients with indwelling urethral catheters and through reviewing the relevant literature.

\section{Tool (I): Structured Interview}

\section{Schedule:}

It includes two parts:

Part (I): included:

a- Bio-Socio-demographic Characteristics of Patients, e.g. age, sex, marital status, level of education, occupation, past and present medical history, present diagnosis, concomitant disease ,current drug intake, previous history of urinary tract infection, hospitalization and catheterization.

b- Information regarding catheterization: reason of catheterization, type of catheter, size, material of catheter, catheter needed to be changed and uribag needed to be changed E-knowledge regarding catheterization

Part (II): It includes observation checklists to assess the implementation of aseptic technique during urinary catheter insertion and care and it includes:

a- Item related to preparation of equipments for urinary catheter insertion. It included observation of the following: 
hand washing before preparing equipments, preparing of sterile equipment and other equipments needed in urinary catheter insertion

b- Items related to preparation of patient for urinary catheterization and catheter insertion technique. It included observation of the following: position of the patient, technique of perineal care, hand washing before procedures, using sterile gloves, attaching the end of catheter to the drainage collector catheter, applying sterile drape, cleansing the uretheral meatus using sterile technique, lubricating and inserting catheter slowly, securing the catheter, attaching drainage bag and recording procedures .

c- Items concerned with catheter care for maintaining the integrity of the sterile closed drainage system and preventing the complications associated with urinary catheter. It included observation for essential aspects of nursing care as checking catheter patency, fixation of catheter position of catheter and uribag, inspecting skin surrounding catheter, daily meatal care, mobilization of patient, time of draining bag evacuation, measuring fluid intake and output. In addition to the items related to health teaching given to the patients about care of catheter

d- Items represented the steps of collecting urine specimen for bacterial culture.

e- Assessment of problems that may arise while catheter in situ as leakage, blockage and disconnection of the tube. It also included signs and symptoms of urinary tract infection.

\section{Tool II: consisted of urine culture}

sheet.

\section{Method}

\section{Preparatory Phase}

It included reviewing of literatures related to the problem and theoretical knowledge of various aspects of the problem using books, articles, periodicals and magazines to develop tools for data collection

\section{Content validity}

The validity of the study tools was done through experts' opinions. Eleven experienced professionals in the medical surgical nursing discipline, as well as in medicine reviewed the materials for comprehensiveness and relatedness. After rigorous revision by the experts, the tools were finalized based on their recommendations.

\section{Pilot Study}

Pilot study was conducted on $10 \%$ of subjects. It was done to test the clarity and practicality of the tools, the results of the data obtained from the pilot study helped in modification of the tools; items were corrected or added as needed. Accordingly, modifications were done and the final form was developed.The subjects of the pilot 
study were not included in the main statistical sample

\section{Field Work}

Field study was conducted during the period from the beginning of May (2012) to the end of October (2012). The researcher visited the hospitals to collect the data by using previous tools. Convenient patients attending the study setting and fulfilling the eligibility criteria were asked to participate in the study. Those who gave their consent were subjected to interviewing using the study tool. They were then randomly assigned to either the study or the control groups. In the patients assigned to the study group, catheter insertion was done under aseptic technique by the researcher in El-Zohor General Hospital and El-Mbra Health Insurance Hospital in Port Said City while in Urology\& Nephrology Center in Mansura University it was inserted by urologist according to hospital policy. (In the patients assigned to the control group, catheter insertion was done according to hospital routine care by both urologist and nurses. A urine sample was taken and analyzed immediately after catheter insertion to ensure they are free from urinary tract infection then; a urine sample was collected from each patient in both groups and sent to the laboratory for culture. Catheter insertion and subsequent care for control group were observed using ASNJ Vol.15 No. 2, 2013 observational checklist (appendix I). The nurses were observed during their clinical practice. For study group, insertion of catheter and continuing care was done by the researcher following aseptic technique and procedures checklist (appendix I). After three days, a second urine sample was collected from patients of both groups sent to the laboratory for culture test.

\section{ADMINISTRATIVE DESIGN}

An official permission for data collection was obtained from directors of El-Zohor General Hospital and ElMbra Health Insurance Hospital in Port Said City, Urology \& Nephrology center in Mansura University and head of urology departments. A formal letter from the Dean of the Faculty of nursing Port Said University was submitted. The aim of the study and procedures were explained to them to attain their cooperation

\section{Ethical Considerations:}

The agreement for participation of the subjects was taken after aims of the study had been explained to them. A verbal informed consent was obtained from the patients to ensure willingness to engage in the study after explaining its purpose. They were informed about their rights to refuse or withdraw at any time with no consequences on their care. The study interventions could not have any 
harmful effect on participants and they were assured that the information collected would be treated confidentially and used for the research purpose only

\section{Statistical Analysis}

At the end of the fieldwork, data sets obtained in different body postures were coded and transformed into coding sheets.

\section{The following statistical measures were used:}

- Number and percent distribution of the studied data for each patient were calculated.

- The collected data were organized, tabulated and statistically analyzed using statistical package for social sciences (SPSS) version 16 (SPSS, Chicago, USA).

- All data were in categorical manner, and frequency and percent distribution were calculated.

- $\quad$ For comparison between groups the chi square $\left(\mathrm{X}^{2}\right)$ or Fisher exact test were used.

For interpretation of results, the $\mathrm{p}$ value $\leq$ 0.05 was considered significant. Significant results were signed by asterisk (*) while NS was used for non significant differences

\section{Results}

Table (1) shows comparison of the socio-demographic characteristics of patients in the study and control groups. It revealed that the most common age group in both study and control groups was from 41 to 60 years $(56.7 \%$ and $70.0 \%$ respectively) with total $(63.3 \%)$ of patients. As regards marital state in both study and control groups, the highest percentages of patients were married $\quad(83.3 \%$ and $90.0 \%$ respectively). Regarding educational level the highest percentage of patients $(40.0 \%)$ in study group were secondary educated while in control group $46.7 \%$ of patients were illiterate with statistically significant difference $(\mathrm{p}=$ 0.003). Finally more than half the patients in study and control groups were housewives $(66.6 \%, 80 \%$ respectively).

Table (2) shows the comparison of the results of urine culture among patients in the study and control groups .It revealed that second urine culture results in study group one fifth of patients $(20.0 \%)$ had positive urine culture samples. In control group half of patients $(50.0 \%)$ had positive urine culture with a total of $(35.0 \%$.) Regarding type of microorganism, Ecoli was high in both studied and control group (13.3\%, 36.7\% respectively) with a total of $(25.0 \%)$, and there were statistically significant differences between study and control groups regarding second sample 
results, and type of microorganism ( $\mathrm{p}=$ $0.015,0.041$ respectively).

Table (3) shows the results of urine culture according to concomitant diseases among patients in study and control groups. It revealed that there was statistically significant difference between concomitant diseases and results of urine culture, patients without concomitant disease $(p=0.008)$ and patients with diabetes $(\mathrm{p}=0.040)$ in the two groups.

Table (4) shows the results of urine culture according to patients' preparation for urinary catheterization in study and control groups. It revealed that there were statistically significant difference between patient preparation for urinary catheterization and results of urine culture test in the two groups regarding washing perineal area with soap and water or saline removing and disposing gloves, wearing sterile gloves, cleansing the ureteral meatus using aseptic technique $(\mathrm{p}=0.004)$ for each and attaching the end of catheter to the drainage collector $(\mathrm{p}=0.001)$.

Table (5) shows the results of urine culture according to urinary catheter_care and health teaching for patient about care of urinary catheter in study and control groups. It revealed that, there were statistically significant differences between urinary catheter care and results of urine culture regarding, hand washing before handling catheter, wearing disposable ASNJ Vol.15 No. 2, 2013 gloves, urine received in clean container, assessing urethral meatus, cleansing perineum with soap and water, maintaining patency of catheter, checking character of urine, encourage fluid intake and maximum mobility, checking securing of urinary drainage system, keeping drainage bag from touching the floor and health teaching for patient about care of urinary catheter $(\mathrm{p}=0.001)$

\section{Discussion}

Most nurses are aware of the importance of aseptic technique but some may be unsure about applying the technique during urinary catheterization. So, the main concern of the present study was to determine the effect of aseptic technique versus routine hospital care on prevention of catheter associated urinary tract infection.

As regards socio-demographic characteristics of patients in relation to age the finding of present study showed that, there was no statistically significant difference between the patients' age and results of urine culture. This finding is supported by Inyama et al. (2011) $)^{(25)}$ who reported that, the relationship between the patients' age and growth of microorganism in their urine was not statistically significant. This finding 
disagrees with Talaat et al. (2010) $)^{(23)}$ who mentioned that patients above 40 years of age had a significantly higher risk of acquiring CAUTIs.

Furthermore, in the present study there was no statistically significant difference between marital status and result of urine culture. This finding is in accordance with Lafi $(2010)^{(26)}$ who demonstrated there is no association between marital status and occurrence of UTI. This finding disagrees with Chedi et al. (2009) ${ }^{(27)}$ who said that married women are more likely to get UTI than their single or widowed counterparts.

As regards patient preparation for urinary catheterization regarding hand washing before urinary catheterization procedures there were statistically significant differences between study and control groups and there were statistically significant difference between hand washing and results urine culture in the two groups. This finding was in accordance with Royal College of Nursing (2012) ${ }^{\text {(28) }}$ which concluded that many health care professionals, including nursing staff, do not perform hand hygiene as often as is required .Health care workers have the greatest potential to spread microorganisms that may result in infection .

Additionally as regards washing perineal area with soap \& water, removing and disposing gloves, there were statistically significant differences between ASNJ Vol.15 No. 2, 2013 study and control groups. These findings were supported by Tsuchida et al. $(2008)^{(29)}$ who reported that nurses had been taught the principles of infection control; however, they may not be able to interpret and implement these principles into practice.

In this respect, there were statistically significant differences between patient preparation for urinary catheterization and results of urine culture in the two groups regarding washing perineal area with soap \& water, removing and disposing gloves. These findings are supported by Talaat et al. (2011) (23) who mentioned that many risk factors associated with acquiring CAUTIs in Alexandria University Hospitals reflected lack of use of infection control measures, e g, hand washing and use of aseptic techniques during catheter insertion.

Regarding wearing sterile
gloves, applying sterile drape,
cleansing the urethral meatus using
sterile technique, there were
statistically significant differences
between studied and control groups.
This finding could result from lack of
nurses' awareness of the importance of
preparing sterile equipment and
following medical and surgical asepsis
to prevent urinary tract infection
associated with catheter. This result is
in line with Yousef (2009) (30) who


reported that regarding nurse's practice there was unsatisfactory level of practice regarding the use of appropriate sterile instruments in the procedures. This finding disagrees with Fink et al. (2012) ${ }^{(31)}$ who reported that most hospitals routinely used sterile technique during indwelling urinary catheter placement insertion.

Moreover, there were statistically significant differences between patient preparation for urinary catheterization and results of urine culture in the two groups regarding wearing sterile gloves, cleansing the urethral meatus using aseptic technique. This finding is supported by Conway \& Larson (2012) ${ }^{(32)}$ who reported that all authors advised using aseptic technique and sterile equipment for inserting catheters in acute-care settings for prevention of CAUTI.

These findings disagreed with Dutta et al. (2012) ${ }^{(33)}$ who stated that techniques (sterile and clean) were found to be equally effective in preventing bacteriuria.Similarly Carapeti et al.(1996) ${ }^{\text {(34) }}$ reported that There was no statistically significant difference between, sterile or clean/ technique with respect to the incidence of catheter associated bacteriuria, but the sterile method was more than twice as expensive

As regards results of urine culture the present study revealed that in the study group, one fifth of patients had positive urine culture while in control group half of ASNJ Vol.15 No. 2, 2013 patients had positive urine culture and there was statistically significant difference between studied and control groups regarding second results of urine culture. This finding is supported by Vieira (2009) ${ }^{(35)}$ who observed that the risk of infection is reduced after standardization of aseptic techniques for bladder catheter insertion and maintenance.

As regards type of microorganism the present study revealed that E-coli was high in both the study and control groups. This finding is supported by Inyama et al. (2011) $^{(25)}$ who said that E. coli is the most prevalent microorganism isolated and was prevalent among the female patients. This could be due to the close proximity of the urethral catheter to the anal passage.This finding disagreed with Wagenlehner $(2006)^{(36)}$ who reported that, the most frequently isolated microorganism was Candida followed by E. coli

As regards urinary catheter care and health teaching for patient about care of urinary catheter the study results revealed that, there were statistically significant differences between hand washing before handling catheter, wearing disposable gloves and results of urine culture. This result is in line with Bond and Harris (2005) ${ }^{(37)}$ and Pratt et al, (2007) ${ }^{(1)}$ who reported 
that, hand hygiene and appropriate use of personal protective equipment, such as gloves had a vital importance in preventing the risk of UTI.

Concerning cleansing perineum with soap and water, there was statically significant difference between cleansing perineum with soap and water and results of urine culture. This finding is congruent with (SARI) National Committee (2011) ${ }^{(38)}$ which clarified that, the meatus washing with soap and water, during daily routine bathing or showering, is all that is required in prevention of CAUTI. This finding is contradicted by Healthcare Infection Control Practices Advisory Committee (2009) ${ }^{(39)}$ and Willson, et al. (2009) (40) who reported that there was no difference in the risk of bacteriuria in patients receiving periurethral care regimens compared to those not receiving them and more study is needed to determine if perineal cleansing has a statistically significant effect on CAUTI rates.

In addition, the results of the current study presented that, there were statically significant differences between maintaining patency of catheter, keeping drainage bag from touching the floor and results of urine culture. These findings are in line with Society of Urologic Nurses and Associates (2010) ${ }^{(41)}$ which reported in clinical practice guidelines for prevention of CAUTI that unobstructed urine flow should be maintained and never disconnect ASNJ Vol.15 No. 2, 2013 the tubing. The drainage bag must never touch the floor.

Also, the present study results revealed that there was statistically significant difference between checking securing of urinary drainage system and results of urine culture. This finding is supported by Turner and Dickens (2011) ${ }^{(42)}$ who found that it is vital to fix the drainage device securely to prevent, discomfort and infection. This finding disagreed with Hooton et al. (2010) ${ }^{(43)}$ who found that indwelling catheters are usually anchored to minimize movement and urethral trauma, but it is not clear whether anchoring helps to reduce CAbacteriuria.

Moreover the present study results revealed that, there was statistically significant difference between health teaching for patient about care of urinary catheter and results of urine culture. This finding is in agreement with Sauter (2011) (44) who found that CAUTI prevention began with educating the patient and family about the patient's current condition and explaining why the patient required a urinary catheter. 
Prevention of Urinary Tract Infection

\section{Conclusion}

From findings of this study, it can be concluded that:

The incidence rate of urinary tract infection among patients with urinary catheter can be decreased through using of aseptic technique for management of urinary catheter compared to using of routine hospital care. This is demonstrated through symptoms and signs and laboratory results.

The risk factors associated with acquiring catheter associated urinary tract infection in the present study are: diabetes mellitus, lack of use of infection control measures, e.g., hand washing ,using sterile equipments, cleansing perineum area using aseptic technique, securing catheter to patient body, wearing gloves, attaching the end of catheter to the drainage collector before catheter insertion, keeping drainage bag from touching the floor, checking securing of urinary drainage system cleansing perineum with soap and water after bowel movement, maintaining patency of catheter, checking character of urine, encouraging fluid intake and maximum mobility and health teaching for the patient about care of catheter.

\section{Recommendations}

In the light of the findings of this study, the following is recommended:

- Providing ongoing in service education for nurses to update their knowledge related to care of patients with indwelling urethral catheter and catheter associated problems.

- Using of aseptic technique practice for insertion and care of indwelling urinary catheter

- Nurses who take care of catheter should be given periodic inservice training stressing the practices of aseptic technique and correct urinary catheter care.

- Teaching of catheterized patients and their caregivers the necessary instructions to manage their catheter and urine drainage bag and also provide them with booklets containing information related to catheter care. 
Table (1): Comparison of the socio-demographic characteristics of patients in the study and control groups

\begin{tabular}{|c|c|c|c|c|c|c|c|c|}
\hline & \multicolumn{2}{|c|}{$\begin{array}{c}\text { Study Group } \\
(\mathrm{N}=\mathbf{3 0})\end{array}$} & \multicolumn{2}{|c|}{$\begin{array}{c}\begin{array}{c}\text { Control group } \\
(\mathrm{N}=\mathbf{3 0})\end{array} \\
\end{array}$} & \multirow{2}{*}{\multicolumn{2}{|c|}{ Total }} & \multirow{2}{*}{\multicolumn{2}{|c|}{ Statistics }} \\
\hline & Total & & Total & & & & & \\
\hline & $\mathbf{N}$ & $\%$ & $\mathbf{N}$ & $\%$ & $\mathbf{N}$ & $\%$ & $\mathbf{X}^{2}$ & p-value \\
\hline $\begin{array}{c}\begin{array}{c}\text { Age group } \\
\text { (years) }\end{array} \\
\text { From } 20-40 \\
\text { From } 41-60 \\
\text { More than } 60\end{array}$ & $\begin{array}{c}10 \\
17 \\
3\end{array}$ & $\begin{array}{l}33.3 \% \\
\mathbf{5 6 . 7 \%} \\
10.0 \%\end{array}$ & $\begin{array}{c}6 \\
21 \\
3\end{array}$ & $\begin{array}{l}20.0 \% \\
\mathbf{7 0 . 0 \%} \\
10.0 \%\end{array}$ & $\begin{array}{c}16 \\
38 \\
6\end{array}$ & $\begin{array}{l}26.7 \% \\
63.3 \% \\
10.0 \%\end{array}$ & 1.42 & 0.49 \\
\hline $\begin{array}{c}\text { Marital state } \\
\text { Married } \\
\text { Single } \\
\text { Window }\end{array}$ & $\begin{array}{c}25 \\
1 \\
4\end{array}$ & $\begin{array}{c}\mathbf{8 3 . 3 \%} \\
3.3 \% \\
13.3 \%\end{array}$ & $\begin{array}{c}27 \\
0 \\
3\end{array}$ & $\begin{array}{c}\mathbf{9 0 . 0 \%} \\
0.0 \% \\
10.0 \%\end{array}$ & $\begin{array}{c}52 \\
1 \\
7\end{array}$ & $\begin{array}{c}86.7 \% \\
1.7 \% \\
11.7 \%\end{array}$ & 1.22 & 0.45 \\
\hline $\begin{array}{c}\text { Educational } \\
\text { level } \\
\text { Illiterate } \\
\text { Primary } \\
\text { Preparatory } \\
\text { Secondary } \\
\text { University or } \\
\text { more }\end{array}$ & $\begin{array}{c}11 \\
1 \\
2 \\
12 \\
4\end{array}$ & $\begin{array}{c}36.7 \% \\
3.3 \% \\
6.7 \% \\
\mathbf{4 0 . 0 \%} \\
13.3 \%\end{array}$ & $\begin{array}{c}14 \\
8 \\
2 \\
5 \\
1\end{array}$ & $\begin{array}{c}\mathbf{4 6 . 7 \%} \\
26.7 \% \\
6.7 \% \\
16.7 \% \\
3.3 \%\end{array}$ & $\begin{array}{c}25 \\
9 \\
4 \\
17 \\
5\end{array}$ & $\begin{array}{c}41.7 \% \\
15.0 \% \\
6.7 \% \\
28.3 \% \\
8.3 \%\end{array}$ & 10.48 & $0.003 *$ \\
\hline $\begin{array}{c}\text { Occupation } \\
\text { Housewife } \\
\text { Working }\end{array}$ & $\begin{array}{l}20 \\
10\end{array}$ & $\begin{array}{l}\mathbf{6 6 . 7 \%} \\
33.3 \%\end{array}$ & $\begin{array}{c}24 \\
6\end{array}$ & $\begin{array}{l}\mathbf{8 0 . 0 \%} \\
20.0 \%\end{array}$ & $\begin{array}{l}44 \\
16\end{array}$ & $\begin{array}{l}73.3 \% \\
26.7 \%\end{array}$ & 1.36 & 0.24 \\
\hline
\end{tabular}

*significant at $\mathrm{P} \leq 0.05$

Table (2): Comparison of the results of urine culture among patients in the study and control groups

\begin{tabular}{|c|c|c|c|c|c|c|c|c|}
\hline & \multirow{2}{*}{\multicolumn{2}{|c|}{$\frac{\text { Study group }(\mathrm{n}=\mathbf{3 0})}{\text { Total A }}$}} & \multirow{2}{*}{\multicolumn{2}{|c|}{$\frac{\text { Control group }(n=30)}{\text { Total } R}$}} & \multirow{2}{*}{\multicolumn{2}{|c|}{ Total }} & \multirow{2}{*}{\multicolumn{2}{|c|}{ Statistics }} \\
\hline & & & & & & & & \\
\hline & $\mathbf{N}$ & $\%$ & $\mathbf{N}$ & $\%$ & $\mathbf{N}$ & $\%$ & $\mathbf{X}^{2}$ & $\begin{array}{c}\text { P- } \\
\text { value }\end{array}$ \\
\hline First sample & & & & & & & & \\
\hline Negative & 30 & $100.0 \%$ & 30 & $100.0 \%$ & 60 & $100.0 \%$ & 0.001 & 1.0 \\
\hline Positive & 0 & $0.0 \%$ & 0 & $0.0 \%$ & 0 & $0.0 \%$ & & \\
\hline Second sample & & & & & & & & \\
\hline Negative & 24 & $80.0 \%$ & 15 & $50 \%$ & 39 & $65 \%$ & 5.93 & $0.015 *$ \\
\hline Positive & 6 & $20.0 \%$ & 15 & $50 \%$ & 21 & $35 \%$ & & \\
\hline $\begin{array}{l}\text { Type of micro- } \\
\text { organism }\end{array}$ & 4 & $13.3 \%$ & 11 & $36.7 \%$ & 15 & $25 \%$ & & \\
\hline $\begin{array}{l}\text { E coli } \\
\text { Klebsiella }\end{array}$ & 2 & $6.7 \%$ & 4 & $13.3 \%$ & 6 & $10 \%$ & 4.60 & $0.041 *$ \\
\hline
\end{tabular}


Prevention of Urinary Tract Infection

Table (3): Results of urine culture according to concomitant diseases among patients in the study and control group

\begin{tabular}{|c|c|c|c|c|c|c|c|c|c|c|c|c|c|c|c|c|}
\hline \multirow[t]{3}{*}{ Variables } & \multicolumn{6}{|c|}{ Negative (39) } & \multicolumn{6}{|c|}{ Positive (21) } & \multirow{2}{*}{\multicolumn{2}{|c|}{ Total }} & \multirow{2}{*}{\multicolumn{2}{|c|}{ Statistics }} \\
\hline & \multicolumn{2}{|c|}{$\begin{array}{l}\text { Study } \\
\text { group } \\
\mathrm{N}=24 \\
\end{array}$} & \multicolumn{2}{|c|}{$\begin{array}{c}\text { Control } \\
\text { group } \\
\mathrm{N}=15 \\
\end{array}$} & \multicolumn{2}{|c|}{ Total } & \multicolumn{2}{|c|}{$\begin{array}{c}\text { Study } \\
\text { control } \\
\mathrm{N}=6 \\
\end{array}$} & \multicolumn{2}{|c|}{$\begin{array}{c}\text { Control } \\
\text { group } \\
\mathrm{N}=15 \\
\end{array}$} & \multicolumn{2}{|c|}{ Total } & & & & \\
\hline & $\mathbf{N}$ & $\%$ & $\mathbf{N}$ & $\%$ & $\mathbf{N}$ & $\%$ & $\mathbf{N}$ & $\%$ & $\mathbf{N}$ & $\%$ & $\mathbf{N}$ & $\%$ & $\mathbf{N}$ & $\%$ & $\mathbf{X}^{2}$ & $\begin{array}{c}\text { p- } \\
\text { value }\end{array}$ \\
\hline None & 10 & 41.7 & 4 & 26.7 & 14 & 35.9 & 1 & 16.7 & 0 & 0.0 & 1 & 4.8 & 15 & 25.0 & 7.05 & 0.008* \\
\hline Diabetes & 11 & 46 & 8 & 53.3 & 19 & 48.7 & 5 & 83.3 & 11 & 73.3 & 16 & 76.2 & 35 & 58.3 & 4.23 & $0.040 *$ \\
\hline $\begin{array}{l}\text { Hyper- } \\
\text { tension }\end{array}$ & 10 & 41.7 & 8 & 53.3 & 18 & 46.2 & 5 & 83.3 & 11 & 73.3 & 16 & 76.2 & 34 & 56.7 & 2.30 & 0.12 \\
\hline Hepatitis & 1 & 4.2 & 0 & 0.0 & 1 & 2.6 & 2 & 33.3 & 1 & 6.7 & 3 & 14.3 & 4 & 6.7 & 3.01 & 0.08 \\
\hline $\begin{array}{l}\text { Ischemic } \\
\text { heart } \\
\text { disease }\end{array}$ & 1 & 4.2 & 1 & 6.7 & 2 & 5.1 & 1 & 16.7 & 1 & 6.7 & 2 & 9.5 & 4 & 6.7 & 0.42 & 0.51 \\
\hline $\begin{array}{l}\text { Hyper- } \\
\text { thyroidism }\end{array}$ & 0 & 0.0 & 1 & 6.7 & 1 & 2.6 & 0 & 0.0 & 0 & 0.0 & 0 & 0.0 & 1 & 1.7 & 0.54 & 0.44 \\
\hline Anemia & 0 & 0.0 & 1 & 6.7 & 1 & 2.6 & 0 & 0.0 & 0 & 0.0 & 0 & 0.0 & 1 & 1.7 & 0.54 & 0.44 \\
\hline
\end{tabular}


Table (4): Results of urine culture according to patients' preparation for urinary catheterization in study and control groups

\begin{tabular}{|c|c|c|c|c|c|c|c|c|c|c|c|c|c|c|c|c|}
\hline \multirow[t]{3}{*}{ Variables } & \multicolumn{6}{|c|}{ Negative (39) } & \multicolumn{6}{|c|}{ Positive (21) } & \multirow{2}{*}{\multicolumn{2}{|c|}{ Total }} & \multirow{2}{*}{\multicolumn{2}{|c|}{ Statistics }} \\
\hline & \multicolumn{2}{|c|}{$\begin{array}{l}\text { Study } \\
\text { group } \\
\mathbf{N}=\mathbf{2 4}\end{array}$} & \multicolumn{2}{|c|}{$\begin{array}{l}\text { Control } \\
\text { group } \\
\mathbf{N}=15\end{array}$} & \multicolumn{2}{|c|}{ Total } & \multicolumn{2}{|c|}{$\begin{array}{l}\text { Study } \\
\text { group } \\
\mathbf{N}=\mathbf{6}\end{array}$} & \multicolumn{2}{|c|}{$\begin{array}{c}\text { Control } \\
\text { group } \\
\mathrm{N}=15\end{array}$} & \multicolumn{2}{|c|}{ Total } & & & & \\
\hline & $\mathrm{N}$ & $\%$ & $\mathrm{~N}$ & $\%$ & $\mathrm{~N}$ & $\%$ & $\mathrm{~N}$ & $\%$ & $\mathrm{~N}$ & $\%$ & $\mathrm{~N}$ & $\%$ & $\mathrm{~N}$ & $\%$ & $X^{2}$ & $\begin{array}{c}\mathrm{P}- \\
\text { value }\end{array}$ \\
\hline $\begin{array}{l}\text { Explaining } \\
\text { procedure to } \\
\text { the patient }\end{array}$ & 24 & 100 & 15 & 100 & 39 & 100 & 6 & 100 & 15 & 100 & 21 & 100 & 60 & 100 & 0.001 & 1.0 \\
\hline $\begin{array}{l}\text { Maintain } \\
\text { patient privacy }\end{array}$ & 24 & 100 & 15 & 100 & 39 & 100 & 6 & 100 & 15 & 100 & 21 & 100 & 60 & 100 & 0.001 & 1.0 \\
\hline $\begin{array}{l}\text { Positioning the } \\
\text { patient } \\
\text { appropriately }\end{array}$ & 24 & 100 & 15 & 100 & 39 & 100 & 6 & 100 & 15 & 100 & 21 & 100 & 60 & 100 & 0.001 & 1.0 \\
\hline $\begin{array}{l}\text { Draping } \\
\text { patient with } \\
\text { blankets }\end{array}$ & 24 & 100 & 15 & 100 & 39 & 100 & 6 & 100 & 15 & 100 & 21 & 100 & 60 & 100 & 0.001 & 1.0 \\
\hline Washing hands & 24 & 100 & 13 & 86.6 & 37 & 94.9 & 6 & 100 & 8 & 53.3 & 14 & 66.7 & 51 & 85.0 & 8.51 & $0.004 *$ \\
\hline $\begin{array}{l}\text { Wearing } \\
\text { disposable } \\
\text { gloves }\end{array}$ & 24 & 100 & 15 & 100 & 39 & 100 & 6 & 100 & 15 & 100 & 21 & 100 & 60 & 100 & 0.001 & 1.0 \\
\hline $\begin{array}{l}\text { Washing } \\
\text { perineal area } \\
\text { with soap \& } \\
\text { water }\end{array}$ & 24 & 100 & 13 & 86.6 & 37 & 94.7 & 6 & 100 & 8 & 53.3 & 14 & 66.7 & 51 & 85.0 & 8.51 & $0.004 *$ \\
\hline $\begin{array}{l}\text { Removing and } \\
\text { dispose gloves }\end{array}$ & 24 & 100 & 13 & 86.6 & 37 & 94.9 & 6 & 100 & 8 & 53.3 & 14 & 66.7 & 51 & 85.0 & 8.51 & $0.004 *$ \\
\hline $\begin{array}{l}\text { Wearing new } \\
\text { sterile gloves }\end{array}$ & 24 & 100 & 13 & 86.6 & 37 & 94.9 & 6 & 100 & 8 & 53.3 & 14 & 66.7 & 51 & 85.0 & 8.51 & $0.004 *$ \\
\hline $\begin{array}{l}\text { Attaching the } \\
\text { end of catheter } \\
\text { to the drainage } \\
\text { collector }\end{array}$ & 24 & 100 & 8 & 53.3 & 32 & 82.1 & 6 & 100 & 2 & 13.3 & 8 & 38.1 & 40 & 66.7 & 11.86 & $0.001 *$ \\
\hline $\begin{array}{l}\text { Applying } \\
\text { sterile drape }\end{array}$ & 24 & 100 & 13 & 86.6 & 37 & 94.9 & 6 & 100 & 8 & 53.3 & 14 & 66.7 & 51 & 85.0 & 8.51 & $0.004 *$ \\
\hline $\begin{array}{l}\text { Cleansing the } \\
\text { urethral } \\
\text { meatus using } \\
\text { aseptic } \\
\text { technique }\end{array}$ & 24 & 100 & 13 & 86.6 & 37 & 94.9 & 6 & 100 & 8 & 53.3 & 14 & 66.7 & 51 & 85.0 & 8.51 & $0.004 *$ \\
\hline
\end{tabular}


Table (5): Results of urine culture according to urinary catheter care and health teaching for patient about care of urinary catheter in the study and control groups

\begin{tabular}{|c|c|c|c|c|c|c|c|c|c|c|c|c|c|c|c|c|}
\hline \multirow[t]{3}{*}{ Variables } & \multicolumn{6}{|c|}{ Negative (39) } & \multicolumn{6}{|c|}{ positive(21) } & \multirow{2}{*}{\multicolumn{2}{|c|}{ Total }} & \multirow{2}{*}{\multicolumn{2}{|c|}{ Statistics }} \\
\hline & \multicolumn{2}{|c|}{$\begin{array}{l}\text { Study } \\
\text { group } \\
\mathrm{N}=24\end{array}$} & \multicolumn{2}{|c|}{$\begin{array}{c}\text { Control } \\
\text { group } \\
\mathbf{N}=15\end{array}$} & \multicolumn{2}{|c|}{ Total } & \multicolumn{2}{|c|}{$\begin{array}{c}\text { Study } \\
\text { group } \\
\mathrm{N}=6\end{array}$} & \multicolumn{2}{|c|}{$\begin{array}{c}\text { Control } \\
\text { group } \\
\mathbf{N}=15\end{array}$} & \multicolumn{2}{|c|}{ Total } & & & & \\
\hline & $\mathbf{N}$ & $\%$ & $\mathbf{N}$ & $\%$ & $\mathbf{N}$ & $\%$ & $\mathbf{N}$ & $\%$ & $\mathbf{N}$ & $\%$ & $\mathbf{N}$ & $\%$ & $\mathbf{N}$ & $\%$ & $\mathbf{X}^{2}$ & $\begin{array}{c}\text { p- } \\
\text { value }\end{array}$ \\
\hline $\begin{array}{l}\text { 1-Hand } \\
\text { washing } \\
\text { Before } \\
\text { handling } \\
\text { catheter }\end{array}$ & 24 & 100 & 8 & 53.3 & 32 & 82.1 & 6 & 100 & 2 & 13.3 & 8 & 38.1 & 40 & 66.7 & 11.86 & 0.001* \\
\hline $\begin{array}{l}\text { 2-Hand } \\
\text { washing } \\
\text { after } \\
\text { a handling } \\
\text { catheter }\end{array}$ & 24 & 100 & 15 & 100 & 39 & 100 & 6 & 100 & 15 & $\begin{array}{c}100 . \\
0\end{array}$ & 21 & 100 & 60 & $\begin{array}{c}100 . \\
0\end{array}$ & 0.001 & 1.0 \\
\hline $\begin{array}{l}\text { 3-Wearing } \\
\text { disposable } \\
\text { gloves }\end{array}$ & 24 & 100 & 8 & 53.3 & 32 & 82.2 & 6 & 100 & 2 & 13.3 & 8 & 38.1 & 40 & 66.7 & 11.86 & 0.001* \\
\hline $\begin{array}{l}\text { 4- Antiseptic } \\
\text { solution was } \\
\text { applied to } \\
\text { the tape }\end{array}$ & 2 & 8.2 & 0 & 00.0 & 2 & 51.1 & 3 & 50 & 0 & 100 & 3 & 14.3 & 5 & 8.3 & 1.49 & 0.22 \\
\hline $\begin{array}{l}\text { 5-Urine } \\
\text { received in } \\
\text { clean } \\
\text { container }\end{array}$ & 10 & 41.7 & 8 & 53.3 & 18 & 46.1 & 0 & 0.0 & 2 & 13.3 & 2 & 9.5 & 20 & 33.3 & 11.86 & 0.001* \\
\hline $\begin{array}{l}\text { 6-Assessing } \\
\text { urethral } \\
\text { meatus }\end{array}$ & 24 & 100 & 8 & 53.3 & 32 & 82.1 & 6 & 100 & 2 & 13.3 & 8 & 38.3 & 40 & 66.7 & 11.86 & $0.001 *$ \\
\hline $\begin{array}{l}\text { 7- cleansing } \\
\text { perineum } \\
\text { with soap } \\
\text { and water }\end{array}$ & 24 & 100 & 8 & 53.3 & 32 & 82.1 & 6 & 100 & 2 & 13.3 & 8 & 38.3 & 40 & 66.7 & 11.86 & $0.001 *$ \\
\hline $\begin{array}{l}\text { 8- } \\
\text { Maintaining } \\
\text { patency of } \\
\text { cath. By }\end{array}$ & 24 & 100 & 8 & 53.3 & 32 & 82.1 & 6 & 100 & 2 & 13.3 & 8 & 38.3 & 40 & 66.7 & 11.86 & $0.001 *$ \\
\hline $\begin{array}{l}\text { 9-Encourage } \\
\text { fluid intake }\end{array}$ & 24 & 100 & 8 & 53.3 & 32 & 82.1 & 6 & 100 & 2 & 13.3 & 8 & 38.3 & 40 & 66.7 & 11.86 & $0.001 *$ \\
\hline $\begin{array}{l}\text { 10-Checking } \\
\text { securing of } \\
\text { urinary } \\
\text { drainage } \\
\text { system and } \\
\text { character of } \\
\text { urine }\end{array}$ & 24 & 100 & 8 & 53.3 & 32 & 82.1 & 6 & 100 & 2 & 13.3 & 8 & 38.3 & 40 & 66.7 & 11.86 & $0.001 *$ \\
\hline $\begin{array}{l}\text { 11- } \\
\text { Encouraging } \\
\text { maximum } \\
\text { mobility }\end{array}$ & 24 & 100 & 8 & 53.3 & 32 & 82.1 & 6 & 100 & 2 & 13.3 & 8 & 38.3 & 40 & 66.7 & 11.86 & 0.001* \\
\hline $\begin{array}{l}\text { 12-Keeping } \\
\text { drainage } \\
\text { bag from } \\
\text { touching the } \\
\text { floor }\end{array}$ & 24 & 100 & 8 & 53.3 & 32 & 82.1 & 6 & 100 & 2 & 13.3 & 8 & 38.3 & 40 & 66.7 & 11.86 & $0.001 *$ \\
\hline $\begin{array}{l}\text { 13-Health } \\
\text { teaching for } \\
\text { the patient }\end{array}$ & 24 & 100 & 8 & 53.3 & 32 & 82.1 & 6 & 100 & 2 & 13.3 & 8 & 38.3 & 40 & 66.7 & 11.86 & $0.001 *$ \\
\hline
\end{tabular}




\section{References}

1. Pratt RJ, Pellowe CM, Wilson JA, Loveday HP, Harper PJ, Jones SR, Dougallb C and Wilcox MH. EPIC 2: National Evidence-based guidelines for preventing healthcareassociated infections in NHS hospitals in England. J Hosp Infect, 2007; 1-64.

2. Ignatavicicius DD and Workman ML. Medical surgical nursing; patient centered collaborative care; Urinary Elimination 7th edition, two, Elseiver, USA, 2013; 1061.

3. Saint S, Kaufman SR, Rogers MA, Baker PD, Ossenkop K and Lipsky BA. Condom versus indwelling urinary catheters: a randomized trial J Am Geriatr Soc; 2006; 54(7), 55-61.

4. Anthony $\mathrm{O}$, Oluwalana O T, Bolatito O, Olaniran O, Adesola $\mathrm{O}$ and Titus O. Urinary Pathogens and Their Antimicrobial Susceptibility in Patients with Indwelling Urinary Catheter. Sierra Leone Journal of Biomedical Research ISSN 20766270; 2010; Vol. 2 (1), 47-53.

5. Oman K S, Makic MB, and Fink R. Nurse-directed interventions to reduce catheter-associated urinary tract infections," American Journal of
Infection Control, 2011; (40), 548-53.

6. Foxley S. Driving down catheter associated infection rates. Nurs Times journal, 2011; 107(29), 148.

7. Klevens RM, Edwards JR, Richards CL, Horan TC, Gaynes RP, Pollock DA. Estimating health care-associated infections and deaths in U.S hospitals, 2002. Public Health Report, 122, 2007; $160-6$.

8. Gokula RM, Smith MA and Hickner J. (2007) Emergency room staff education and use of a urinary catheter indication sheet improves appropriate use of Foley catheters. American Journal of Infection Control, 2007; 35(9), 589-93.

9. Institute for Healthcare Improvement. How-to Guide: Prevent Catheter-Associated Urinary Tract Infections. Prevent catheter-associated urinary tract infections by implementing the four components of care recommended in this guide, 2011; p.1-17.

10. Curran E and Murdoch $H$. Aiming to reduce catheter-associated urinary tract infections (CAUTI) 
by adopting a checklist and bundle to achieve sustained system improvements. Journal of Infection Prevention; 2009; 10: 2, 57-61.

11. Behiry IK, El Hedeki Sh Kh. and Mahfouz M. Candida Infection Associated with Urinary Catheter in Critically ill Patients Identification Antifungal Susceptibility and Risk Factors. Research Journal of Medicine and Medical Sciences, 2010; 5(1), 79-86.

12. Elpern EH, Killeen K, Ketchem A, Wiley A, Patel G, and Lateef $\mathrm{O}$. (2009): Reducing use of indwelling urinary catheters and associated urinary tract infections .American Journal of Critical Care, 2009; 18(6); 535.

13. López MJ and Cortés JA. Urinary tract colonization and infection in critically ill patients. Med Intensiva; 2012; 36(2), 143-551.

14. Hilton PA. Fundamental Nursing Skills, Eliminating, WHURR, UK, $2005 ; 208$.

15. Penny B. and Chris H. Best practice in urinary catheterization and catheter care. Nursing times net VOL: 101, ISSUE: 08, 2005; 54.

16. Palmer J A, Lee G M, Dutta-Linn M $\mathrm{M}$, Wroe $\mathrm{P}$ and Hartmann $\mathrm{C}$ W. Including Catheter-Associated
Urinary Tract Infections in the 2008 CMS Payment Policy: A Qualitative Analysis . Society of Urologic Nurses and Associates; Urologic Nursing, 33(1), 2013; 18.

17. Khan SA. Nosocomial Infection: General Principles and the consequences, Importance of Its control and an outline of the control policy - A ERVIEW Article, Bangladesh Medical Journal, 2009; 38 (2), 60.

18. Rowley S and Clare S. Improving standards of aseptic practice through an ANTT trust-wide implementation process: a matter of prioritisation and care. Journal of Infection Prevention, 2009; 1820.

19. Rowley S and Clare S. ANTT: a standard approach to aseptic technique. Source The Association of Safe Aseptic Practice. Nurs Times; 2011; Vol 107(36), 12-4.

20. Collins AS. Preventing Health Care-Associated Infections. In: Patient Safety and Quality: An Evidence-Based Handbook for Nurses. Agency for Healthcare Research and Quality, chapter 41 2008; Vol (2), 547-560. 
21. Bissett L. Reducing the risk of catheter-related urinary tract infection. Nursing Times, 101, 12, 2005; 64-5.

22. Mangnall Jand Watterson L. Principles of aseptic technique in urinary catheterization; Nursing Standard 21(8), 2006; 49-56.

23. Talaat M, Hafez S, Saied T, Elfeky R, El-Shoubary Wand Pimentel G. Surveillance of catheter-associated urinary tract infection in 4 intensive care units at Alexandria university hospitals in Egypt . American Journal of Infection Control, 2010; 38(3); 222,8 .

24. Dobson A. Calculating sample size, 'Trans Menziez Foundation, 1984; 7:75-9.

25. Inyama HK, Revathi G, Musandu J and Odero T. The incidence of nosocomial urinary tract infections: kenyatta national hospital - intensive care unit. Baraton Interdisciplinary Research Journal Vol 1 (2), 2011; 12 -21 .

26. Lafi S Y. Assessment of Factors contributed to Urinary Tract Infection (UTI) incidence in Sulaimani Teaching Hospital. Journal of Zankoy Sulaimani, Part A, 2010; 13(1); 21 30.
27. Chedi BAZ, Wannang NN , Halliru MAand Bichi LA.A Seven Months Retrospective Study On Urinary Tract Infection Among Patients At Aminu Kano Teaching Hospital Kano Nigeria. Bayero Journal of Pure and Applied Sciences, 2009; 2(2), $95-98$.

28. Royal College of Nursing. Catheter Care: RCN Guidance for Nurses. RCN, London, 2009.

29. Tsuchida T, Makimoto K, Ohsako S, Fujino $M$, Kaneda $M$ and Miyazaki T. Relationship between catheter care and catheter-associated urinary tract infection at Japanese general hospitals: A pros- pective observational study . International Journal of Nursing Studies, 45, 2008; 352-61.

30. Yousef SH. assessment of nurses' practice for urinary catheterization and catheter care for patients with long term urinary catheter Unpublished master thesis, Faculty of Nursing, University of Benha,2009;110-12.

31. Fink R, Gilmartin H, Richard A, Capezuti E, Boltz M and Wald H. Indwelling urinary catheter management and catheterassociated urinary tract infection 
Prevention of Urinary Tract Infection

prevention practices in Nurses

Improving Care for Health system

Elders hospitals. Association for

Professionals in Infection Control and

Epidemiology ,American Journal of

Infection Control, 2012;.1-6.

32. Conway LJ and Larson E L. Guidelines to prevent catheterassociated urinary tract infection. 1980 to 2010; Heart Lung; 41(3), $2012 ; 271-83$.

33. Dutta M, Verma P and Mandal AK. Comparison of effectiveness of sterile vs. clean technique for indwelling catheter care in preventing urinary tract infection .Nursing and Midwifery Research Journal, 2012; Vol-8,.29-37.

34. Carapeti EA, Andrews SM, Bentley PG. Randomized study of sterile versus non-sterile urethral catheterization. Ann R Coll Surg Engl; 78, 1996; 59-60.

35. Vieira FA. Nursing actions to prevent urinary tract infection associated with long-standing bladder catheter. Einstein; Vol 7, 2009; 372-375.

36. Wagenlehner FM, Loibl E, Vogel H, Naber KG. Incidence of nosocomial urinary tract infections on a surgical intensive care unit and implications for management. Int $\mathbf{J}$ Antimicrob Agents. 28 Suppl. 1, 2006; S86-90.
37. Bond $\mathrm{P}$ and Harris C. Best Practice in urinary catheterization and catheter care. Nurs Times; 2005; 101(8), 54 - 8 .

38. Strategy for Antimicrobial Resistant in Ireland (SARI) National Committee. Health Protection Surveillance Centre. Dublin. Guidelines for prevention of catheter associated urinary tract infection 2011; 6-20.

39. Healthcare Infection Control Practices Advisory Committee. Guideline for prevention of catheter associated urinary tract infections 2009. On 3/12/2009 from

http://www.cdc.gov/ncidod/dhqp/p df/guidelines/CAUTI_Guideline20 09final.pdf.

40. Wilson M, WildeM., Webb ML, Thompson D, Parker Dand Harwood J. Nursing interventions to reduce the risk of catheterassociated urinary tract infection: Part 2: Staff education, monitoring and care techniques. J. Wound Ostomy Continence Nurse, 2009; 36(2), 137-154.

41. Society of Urologic Nurses and Associates (SUNA) .Clinical Practice Guidelines; Prevention \& Control Of Catheter- Associated Urinary Tract Infection 
Prevention of Urinary Tract Infection

(CAUTI),2011;Retrived suna@ajj.com at:

42. Turner B, Dickens N .Long-term urethral catheterization. Nursing Standard journal, 25, (24), 2011; 4956.

43. Hooton TM, Bradley SF and Cardenas DD. Diagnosis, prevention, and treatment of catheter-associated urinary tract infection in adults: 2009 International clinical practice guidelines from the Infectious Diseases Society of America. Clin Infect Dis; 50(6), 2010; 625-63.

44. Sauter J. preventing catheter associated urinary tract infections;
Nursing Critical Care; 2011; Vol

$$
7,17-21 \text {. }
$$

